\title{
Uroš Mozetič: Bibliography
}

\section{Monographs}

1991. "Sprejemanje dramatike Eugena O'Neilla na Slovenskem.” MA Thesis, University of Ljubljana.

1998. "Premiki pripovednega gledišča v medbesedilnem stiku: Dubliners in Ljudje iz Dublina Jamesa Joycea." PhD diss., University of Ljubljana.

2000. Problem pripovednega gledišca in žariščenja pri prevajanju proznih besedil. Ljubljana: Znanstveni inštitut Filozofske fakultete.

2009. Miracles of Rare Device: English Verse from the Elizabethans to the Moderns, 1st print. Ljubljana: Znanstvena založba Filozofske fakultete. (Co-authored with Mojca Krevel).

2012. Miracles of Rare Device: English Verse from the Elizabethans tothe Moderns, 2nd print. Ljubljana: Znanstvena založba Filozofske fakultete. (Co-authored with Mojca Krevel).

\section{Studies and Articles}

1991. “Instantni pogledi na delo in življenje Jamesa Joycea: ugovori in pripombe.” Delo, February 21, 14.

1991. "Translator as a Composer: A Comparison Between the Original and the Slovene Translation of the 'Sirens' Episode in James Joyce's Ulysses." In Trends in Contemporary British Novel, edited by Meta Grosman and Uroš Mozetič, 13-36. Ljubljana: Faculty of Arts.

1992. "Kako je z ameriško književnostjo med neameriškimi bralci: medkulturno proučevanje in posredovanje." Delo, June 24,13.

1992. "Lahko (že) govorimo o umiranju ali smrti literarnega besedila?: učiti ali ne učiti (angleško književnost)." Delo, October 8, 15.

1992. "Uporaba prevodnega pesemskega besedila pri pouku književnosti v srednji šoli: Robert Frost: Stopping by Woods on a Snowy Evening (Ob gozdu na zimski večer)." Vestnik DTJK 26 (1/2): 60-69.

1995. "The Impact of Translation Deviation upon the Reception of Eugene O'Neill's Plays in Slovenia." In American Literature for Non-American Readers: Crosscultural Perspectives on American Literature, edited by Meta Grosman, 123-38. Frankfurt am Main: P. Lang.

1995. "Parallel Reading to Teach Poetry: Comparing W. H. Auden Originals with Their Translations." In English Studies 6, edited by Alain Sinner, 165-75. Luxembourg: Centre Universitaire de Luxembourg.

1995. “Pouk poezije v medbesedilnem kontekstu.” Vestnik 29 (1/2): 91-100. 
1997. "(Nobel)lovec v močvirju: zanimivost in zagonetnost severnoirskega pesnika Heaneya." Delo, November 27, 49.

1997. "Splošni in posebni problemi prevajanja angleških in ameriških leposlovnih besedil v slovenščino.” In Književni prevod, edited by Meta Grosman and Uroš Mozetič, 57-73. Ljubljana: Znanstveni inštitut Filozofske fakultete.

1997. "Spremembe pripovednega gledišča pri prevajanju angleških proznih besedil v slovenščino." In Kriteriji literarnega prevajanja: 21. prevajalski zbornik, edited by Majda Stanovnik, 35-41. Ljubljana: Društvo slovenskih književnih prevajalcev.

1998. "Le tratenje moči v prepad sramote, le to je strast: premislek o drami čustev, ki bi bila lahko to, kar so, če ne bi bila to, kar niso." Gledališki list Mestnega gledališča ljubljanskega 47 (4): 32-40.

1998. "Literature as a Comparative Discourse: Parallel Readings in Two Languages." In Language Policy and Language Education in Emerging Nations: Focus on Slovenia and Croatia and with Contributions from Britain, Austria, Spain, and Italy, edited by Robert de Beaugrande, Meta Grosman, and Barbara Seidlhofer, 49-53. Stamford, London: Ablex Publishing Corp.

2000. "Predstavljanje govora in mišljenja v luči pripovednega gledišč(enj)a in žarišč(enj)a: Ljudje iz Dublina Jamesa Joycea." Primerjalna književnost 23 (2): 85-108.

2002. “E. E. Cummings: človek kot umetnik - utopija v nastajanju.” Nova revija 21 (247/248): $173-97$.

2002. "A Holistic Model for the Study of Poetry." Vestnik 36 (1/2): 119-30.

2004. "E. E. Cummings: the Art of the Poetry of Translating his Poetry." British and American Studies 10: 127-36.

2004. "Narrative Perspective and Focalisation in Translating Fictional Narratives." ELOPE 1 (1/2): 209-23.

2005. "The Rack-Brain Pencil-Push of hurt-in-hiding: Translating the Poetry of Seamus Heaney into Slovene.” ELOPE 2 (1/2): 277-91.

2005. “Seamus Heaney: Irska kot anima mundi." Nova revija 24 (273/274): 232-54.

2006. "E. E. Cummings: From Parenthesis to Personality: (Part 1)." In Literary Criticism as Metacommunity: A Festschrift for Meta Grosman (i.e. ELOPE 3 (1/2), 2006), edited by Smiljana Komar and Uroš Mozetič, 201-12. Ljubljana: Slovensko društvo za angleške študije.

2007. "E. E. Cummings: From Parenthesis to Personality: (Part 2)." ELOPE 4 (1/2): 121-34.

2007. "From Doublevalent to Monovalent Discourse: the Role of the Translator in Mediating Heteroglossia and Heteropsia in a Fictional Narrative." Acta Neophilologica 40 (1/2): 197-205.

2007. "How Free and How Indirect: Modernist Narrative Techniques in the Translation Process." In English Studies in Flux: New Peaks, New Shores, New Crossings, edited by Eva-Maria Graf and Allan James, 69-78. Tübingen: Gunter Narr Verlag.

2007. "Ob prevajanju pesmi O njegovem delu v angleški govorici Seamusa Heaneyja." Hieronymus 1 (1/2): 103-13. 
2009."Weaving by Day, Unravelling by Night: the Critical and Translation Reception of the Poetry of Seamus Heaney in Slovenia." In Sprache und Literatur durch das Prisma der Interkulturalität und Diachronizität: Festschrift für Anton Janko zum 70. Geburtstag = Jezik in književnost skozi prizmo medkulturnosti in diahronosti: jubilejni zbornik za Antona Janka ob 70-letnici, edited by Marija Javor Briški, Mira Miladinović Zalaznik, and Stojan Bračič, 272-86. Ljubljana: Znanstvena založba Filozofske fakultete.

2010. "Between Inevitability and Struggle: the Problem of Explication in Translating English Literary Texts into Slovene." In Challenges in Translation, edited by Hortensia Pârlog, Luminița Frențiu, and Loredana Frăţilă, 71-81. Timişoara: Editura Universităţii de Vest.

2014. "Explicitation and Implicitation as Translation Universals and Their Occurrences in the Slovene Translation of Anglo-American Literary Texts." ELOPE 11 (2): 101-14.

2015. "Ideological Readings of Eugene O'Neill's Plays Anna Christie and Desire under the Elms in Slovene Theatres before and after World War II." In From Theory to Practice 2014: Proceedings of the Sixth International Conference on Anglophone Studies, September 4-5, 2014, Tomas Bata University in Zlin, Czech Republic, edited by Gregory Jason Bell, and Katarína Nemčoková, 163-69. Zlín: Univerzita Tomáše Bati ve Zlíně.

\section{Critical Introductions}

1989. Walt Whitman - enfant terrible in prerok nove Amerike, Intoduction to Walt Whitman, by Walt Whitman, 107-130. Ljubljana: Mladinska knjiga.

1994. W. H. Auden: poezija ne sproži ničesar, Intoduction to Wyston Hugh Auden, by Wyston Hugh Auden, 91-110. Ljubljana: Mladinska knjiga.

1997. Spreminjajoče se oko-ki-vse-spreminja: vizija in poezija Allena Ginsberga in beatniške generacije, Intoduction to Blebetanje neskončnosti, by Allen Ginsberg, I-XXIII. Ljubljana: KUD France Prešeren.

1999. Walt Whitman - bard za vse čase, Introduction to Travne bilke: izbrane pesmi, by Walt Whitman, 146-65. Ljubljana: Mladinska knjiga.

2008. Introduction to Zapuščanje otoka, by Paul Muldoon, 80-89. Ljubljana: Študentska založba.

2012. "Poseben vonj po sprijenosti, ki, upam, preplavlja moje zgodbe", Introduction to Dublinčani, by James Joyce, 277-306. Ljubljana: Mladinska knjiga.

2013. Novica Novaković "Včasih kot zrak, včasih kot zemlja..." Introduction to Majhne stvari, by Novica Novaković, 73-81. Ljubljana: Nova revija.

\section{Book Reviews}

1989. "Kako do večje bralne učinkovitosti?” Review of Bralec in književnost, by Meta Grosman. Delo, October 5, 4-5.

1989. "Pomemben prispevek kritiški misli." Review of Literarne in gledališke interpretacije in presoje, by Mirko Jurak. Naši razgledi 38 (2): 42.

1992. "Klinarjevih Sto slovenskih vrhov." Review of Sto slovenskih vrhov, by Stanko Klinar. Planinski vestnik 92 (3): 133-34.

1994. "Romanje grofiča Brina Dateljnaka." Review of Labirinti iz papirja, by Andrej Blatnik. Razgledi 17, September 16, 28. 
1995. "Ameriška književnost v medkulturni interakciji." Review of American Literature for Non-American Readers: Cross-Cultural Perspectives on American Literature, edited by Meta Grosman. Vestnik 29 (1/2): 299-303.

1995. "Priročniki z odgovori na ključno maturitetno vprašanje: recenzija priročnika Književnost in matura iz angleščine Mete Grosman in Saše Benulič.” Review of Književnost in jezik za maturo iz angleščine, by Meta Grosman and Saša Benulič. Delo, January 12, 10.

1995. "Sprejemanje ameriške literature pri tujih bralcih: književnost v medkulturni interakciji." Review of American Literature for Non-American Readers: Cross-Cultural Perspectives on American Literature, edited by Meta Grosman. Delo, November 23, 13.

\section{Editor}

1991. Trends in Contemporary British Novel 1940-1990: A Yugoslav View. Edited by Meta Grosman and Uroš Mozetič. Ljubljana: Faculty of Arts and Sciences, English Department.

Auden, Wystan Hugh. 1994. Wystan Hugh Auden. Edited by Uroš Mozetič. Ljubljana: Mladinska knjiga, 1994.

1997. Književni prevod. Edited by Meta Grosman and Uroš Mozetič. Ljubljana: Znanstveni inštitut Filozofske fakultete.

Whitman, Walt. 1999. Travne bilke: [izbrane pesmi]. Edited by Uroš Mozetič. Ljubljana: Mladinska knjiga.

Cummings, Edward Estlin. 2006. Življenje v oklepaju. Edited by Uroš Mozetič. Ljubljana: Mladinska knjiga.

Prešeren, France. 2008. Izbrane pesmi = Selected poems. Edited by Uroš Mozetič. Ljubljana: Mladinska knjiga. Reissued in 2014.

2004-2016. ELOPE, English Language Overseas Perspectives and Enquiries, edited by Smiljana Komar and Uroš Mozetič. Ljubljana: Slovene Association for the Study of English / Ljubljana University Press, Faculty of Arts.

\section{Translator}

\subsection{Monographs}

Kirn, Andrej, ed. 1988. Znanost v družbenovrednotnem svetu: zbornik. Translated by Uroš Mozetič et al. Ljubljana: Delavska enotnost.

Whitman, Walt. 1989. Walt Whitman. Translated by Uroš Mozetič. Ljubljana: Mladinska knjiga. Four poems translated by Peter Levec.

Allen, Woody. [1992]. Kugelmassova zgodba: kratka radijska igra. Translated by Uroš Mozetič. [Ljubljana]: Radio Slovenija, Uredništvo igranega programa.

Auden, Wystan Hugh. 1994. Wystan Hugh Auden. Translated by Uroš Mozetič. Ljubljana: Mladinska knjiga.

Šteger, Aleš. 1997. Solitude. Translated by Uroš Mozetič. Chattanooga: Poetry Miscellany.

Whitman, Walt. 1999. Travne bilke: [izbrane pesmi]. Translated by Uroš Mozetič. Ljubljana: Mladinska knjiga. 
Sparks, Nicholas. 2002. Beležnica. Translated by Jana Kranjec Menaše, verses translated by Uroš Mozetič. Ljubljana: Mladinska knjiga.

Cummings, Edward Estlin. 2006. Življenje v oklepaju. Translated by Uroš Mozetič. Ljubljana: Mladinska knjiga.

Makarovič, Svetlana. 2006. Gal in the Gallery. Translated by Uroš Mozetič. Ljubljana: National Gallery of Slovenia.

Mahkota, Tina, and Gabriel Rosenstock, eds. 2007. Amanairis: antologija sodobne književnosti $v$ irščini. Translated from English by Uroš Mozetič et al. Ljubljana: Društvo slovenskih pisateljev.

Muldoon, Paul. 2008. Zapuščanje otoka. Translated by Uroš Mozetič. Ljubljana: Študentska založba.

Sam, Anej, ed. 2013. Soul of Slovenia. Translated by Uroš Mozetič et al. Ljubljana: Jasa.

\subsection{Exhibition Catalogues}

Smrekar, Andrej, ed. 1991. Tone Kralj: zgodnja grafika, 1921-1932: iz zbirke Božidarja Jakca: [Galerija Božidar Jakac, Lamutov likovni salon, od 21. junija do 31. julija 1991]. Translated by Uroš Mozetič. Kostanjevica na Krki: Galerija Božidarja Jakca.

Smrekar, Andrej, and Dragica Trobec Zadnik, eds. 1993. Rihard Jakopič, To sem jaz, umetnik ...: življenje in delo, Mestni muzej Ljubljana, Kulturno-informacijski center Križanke: izbrane slike iz javnih in državnih zbirk, Narodna galerija. Abstracts translated by Uroš Mozetič. Ljubljana: Narodna galerija, Mestni muzej.

Tomše, Ida, ed. 1994. Jordan: [razstava slik in risb, Lamutov likovni salon, Kostanjevica na Krki, od 16. junija do 15. septembra 1994]. Translated by Uroš Mozetič. Kostanjevica na Krki: Galerija Božidar Jakac.

Boljka, Janez. 1997. Donacija Janeza Boljke: Galerija Božidar Jakac, Kostanjevica na Krki. Translated by Uroš Mozetič. Ljubljana [i. e.] Kostanjevica na Krki: Galerija Božidar Jakac.

Jaki, Barbara, ed. 1999. Painting and Sculpture in Slovenia from 13th to the 20th Century: Guide to the Permanent Collection, 1st ed. Translated by Uroš Mozetič. Ljubljana: National Gallery of Slovenia.

Jaki, Barbara, ed. 2001. Painting and Sculpture in Slovenia from 13th to the 20th Century: Guide to the Permanent Collection, 2nd ed. Translated by Uroš Mozetič. Ljubljana: National Gallery of Slovenia.

Jaki, Barbara, ed. 2004. National Gallery of Slovenia: Guide to the Permanent Collection: Painting and Sculpture in Slovenia from 13th to the 20th Century, 3rd ed. Translated by Uroš Mozetič. Ljubljana: National Gallery of Slovenia. 


\subsection{Translated Poems, a Nonlecture and an Interview}

Dylan, Thomas. 1989. "Če bi me vzdražilo ljubezensko trenje." Translated by Uroš Mozetič. Dialogi 25 (3/4): 59-61.

The translation also includes the poems "Predvsem, ko oktobrski veter," "Nikoli se ne odeni v pozabo teme," "Dogajanje v vremenu srca," and "Ko bi svetilke gorele."

Hirsch, Edward. 1989. "V spomin na Dennisa Turnerja, 1946-1984." Translated by Uroš Mozetič. Literatura 1 (5): 56-62.

The translation also includes the poems "Divja hvaležnost," "Omen," "Edward Hopper in hiša ob progi (1925)," and "Mršavi konj (Kitajska slika dinastije Yüan)."

Katrovas, Richard. 1989. "Ena." Translated by Uroš Mozetič. Literatura 1 (5): 74-80.

The translation also includes the poems "3. 1970," “14," "8. 1975," "Oče, vem," and "Zeleni zmaji mokro perje."

St. John, David. 1989. “Lutke.” Translated by Uroš Mozetič. Literatura 1 (5): 92-98.

The translation also includes the poems "Obala," "Elegija," and "Počasen ples."

Bloom, Harold. 1990. “Transumpcija: k diahronični retoriki (praznine, listi, kriki).” Translated by Uroš Mozetič. Literatura 2 (9): 166-88.

Ehrhart, William D. 1990. "Pesmi.” Translated by Uroš Mozetič. Naši razgledi 39 (3): 91.

The translation includes the poems "Dvakrat ogoljufana," and "Tistim, ki so se vrnili utrujeni."

Ehrhart, William D. 1990. “Tistim, ki so se vrnili utrujeni.” Translated by Uroš Mozetič. Dialogi 26 (7/8/9): 17-18.

The translation also includes the poems "Azijskim zmagovalcem," "To ni pesem o vojni," "Dvakrat ogoljufana," "Naslednji korak," and "Pismo preživelim."

Cummings, Edward Estlin. 1997. [Pesmi] Translated by Uroš Mozetič. Razgledi 21, november 12, 21, 25, 27.

The translation includes the poems "ker je občutje prvo," "ko se te dotikam pravim (in je Pomlad)," "rad imam svoje telo, ko je s tvojim," and "tako dolgo je že, kar je moje srce s tvojim."

Cummings, Edward Estlin. 2002. "Jaz \& moji starši: nepredavanje številka ena." Translated by Uroš Mozetič. Nova revija 21 (247/248): 165-72.

Cummings, Edward Estlin. 2002. "Pesmi: Amores.” Translated by Uroš Mozetič. Nova revija 21 (247/248): [141]-64.

Šteger, Aleš. 2004. "Tree Cut by Fire." Translated by Uroš Mozetič. Verse 21(1/3): 541.

Heaney, Seamus. 2005. "Iz zbirke Električna luč." Translated by Uroš Mozetič. Nova revija 24 (273/274): 194-212.

The translation includes the poems "Male visoke pesmi o Asturiji," "Znani svet," "O njegovem delu v angleškem jeziku: v spomin Tedu Hughesu," "Električna luč," "Senci Zbigniewa Herberta," "Ekloga Bannske doline," "Fragment," "Telesa in duše," and "Od Clonmanyja k Ahascraghu."

Heaney, Seamus. 2005. "Od časa do časa: poezija in tisočletje.” Translated by Uroš Mozetič. Nova revija 24 (273/274): 213-20. 
Heaney, Seamus. 2005. "O elegijah, eklogah, prevodih, prelivanjih: pogovor s Seamusom Heaneyem." ["On Elegies, Eclogues, Translations, Transfusions: An Interview with Seamus Heaney," interview by Rui Carvalho Homen.] Translated by Uroš Mozetič. Nova revija 24 (273/274): 221-31.

Tate, James. 2007. “Stari vojščaki.” Translated by Uroš Mozetič. Nova revija 26 (299): 106-8.

7 Poet(ry)

1997. “Galerija zavrženih stvari.” Nova revija 16 (187/188): 38-39.

2001. “Lošinj.” Nova revija 20 (234/235): 36-42.

2002. "Po-svetila." Nova revija 21 (247/248): 27-32.

2003. "[Pesmi]". In Dnevi poezije in vina $=$ Days of Poetry and Wine, Medana 2003, edited by Aleš Šteger and Mojca Žagar Karer, 194-205. Ljubljana: Študentska založba.

Poems translated by the author: "Galerija zavrženih stvari" = "Gallery of Discarded Things"; "Ko sem prepeval vstopne molitve" = "As I was Saying My Introit Prayers"; "Lošinj" = "Lošinj"; "Tango" = "Tango."

2004. “Oblak védenja." Nova revija 22 [i.e. 23] (263/264): 56-62.

2006. "Križev pot za slepe." Nova revija 24 [i.e. 25] (285/286): 20-25. 